Volume 16, No. 2, Juli 2019

Page: 769- 774

\title{
PENGETAHUAN DAN PRAKTIK PEMBERANTASAN SARANG NYAMUK TERHADAP TEMPAT PERINDUKAN VEKTOR DBD
}

\author{
Fitra Hidayat, Noraida \\ Poltekkes Kemenkes Banjarmasin Jurusan Kesehatan Lingkungan \\ Jl. Mistar Cokrokusumo No. 1A Banjarbaru Kalimantan Selatan 70714 \\ Email: fitrahidayat444@gmail.com
}

\begin{abstract}
Knowledge and Practices of Eradicating Mosquito Nests against DHF Vector Breeding Sites. The Puskesmas Banjarbaru Utara includes the Mentaos and Loktabat Utara Urban Villages. From year to year the two urban villages always have DHF cases repeatedly. The purpose of this study was to determine the relationship between knowledge and practice of eradicating mosquito nests against DHF vector breeding sites in the Puskesmas Banjarbaru Utara. This study is an analytical study with cross-sectional design. The sample in the study were 99 family heads. The study was conducted in November 2018 until January 2019. Data were analyzed using the chi-square test. The results showed that there was a relationship between knowledge of mosquito nest eradication and DHF vector breeding sites because of the value of $p(0.002)<\alpha(0.05)$ and there was also a relationship between the practice of eradicating mosquito nests and vector breeding sites because of the $p(0.000)<\alpha(0.05)$.
\end{abstract}

Keywords: DHF; Knowledge; Practice; Eradication of Mosquito nests

\begin{abstract}
Abstrak: Pengetahuan dan Praktik Pemberantasan Sarang Nyamuk Terhadap Tempat Perindukan Vektor DBD. Wilayah Puskesmas Banjarbaru Utara meliputi Kelurahan Mentaos dan Loktabat Utara. Dari tahun ke tahun kedua kelurahan tersebut selalu terjadi kasus DBD secara berulang. Tujuan penelitian ini untuk mengetahui hubungan pengetahuan dan praktik Pemberantasan Sarang Nyamuk (PSN) terhadap tempat perindukan vektor DBD di wilayah Puskesmas Banjarbaru Utara. Penelitian ini merupakan penelitian analitik dengan desain potong-lintang. Sampel dalam penelitian sebanyak 99 kepala keluarga. Penelitian dilaksanakan pada bulan November 2018 hingga Januari 2019. Data dianalisis menggunakan uji chi-square. Hasil penelitian menunjukkan bahwa terdapat hubungan pengetahuan PSN dan tempat perindukan vektor DBD karena nilai $p(0,002)<\alpha(0,05)$ dan terdapat juga hubungan praktik PSN dan tempat perindukan vektor DBD karena nilai $p(0,000)<\alpha(0,05)$.
\end{abstract}

Kata Kunci: DBD; Pengetahuan; Praktik; Pemberantasan Sarang Nyamuk

\section{PENDAHULUAN}

Pada tahun 1953 penyakit Demam Berdarah Dengue (DBD) pertama kali ditemukan di Manila (Filipina), dan kemudian menyebar ke berbagai negara. Data dari seluruh dunia menunjukkan Asia menempati urutan pertama dalam jumlah penderita DBD setiap tahunnya. Sementara itu, World Health Organization (WHO) terhitung sejak tahun 1968 hingga tahun 2009 mencatat bahwa negara Indonesia sebagai negara dengan kasus DBD tertinggi di Asia Tenggara [1].

Pemerintah Indonesia melalui Dinas Kesehatan telah mensosialisasikan kepada masyarakat tentang upaya pengendalian vektor DBD yang dapat dilakukan secara mandiri oleh masyarakat di rumah. Program tersebut dikenal dengan sebutan Pemberantasan Sarang Nyamuk dengan Menutup, Menguras dan Mendaur ulang Plus (PSN 3M Plus). PSN 3M Plus memberikan penjelasan tentang perilaku menghilangkan sarang nyamuk vektor DBD dan langkah untuk mengurangi kontak atau gigitan nyamuk Aedes. Mengingat bahwa sarang nyamuk Aedes banyak terdapat di dalam rumah sehingga tindakan ini dinilai perlu dilakukan oleh masyarakat untuk menekan angka kejadian DBD [2]. 
Pengetahuan yang masih kurang dan tingkat kesadaran yang rendah disinyalir memberikan dampak yang kurang baik terhadap kualitas kesehatan masyarakat, kurangnya pengetahuan dengan indikasi rendahnya kesadaran akan mengurangi perilaku masyarakat terhadap pemeliharaan kesehatan terutama dalam upaya pencegahan DBD dan dari pengalaman terbukti bahwa perilaku yang didasari oleh pengetahuan dan kesadaran akan lebih langgeng daripada perilaku yang tidak didasari oleh pengetahuan dan kesadaran maka tidak akan berlangsung lama[3].

Wilayah Puskesmas Banjarbaru Utara meliputi Kelurahan Mentaos dan Loktabat Utara, dimana dari tahun ke tahun kedua kelurahan tersebut selalu terjadi kasus DBD secara berulang. Berdasarkan data DBD Kota Banjarbaru, untuk Kelurahan Mentaos kejadian DBD di tahun 2015 sebanyak 13 kasus dan terjadi peningkatan di tahun 2016 menjadi 24 kasus sehingga termasuk daerah endemis DBD. Pada tahun 2017 penderita DBD berdasarkan golongan umur ada 14 kasus. Pada tahun 2018 penderita DBD berdasarkan umur dan jenis kelamin terbanyak terdapat di Wilayah Puskesmas Banjarbaru Utara dengan jumlah penderita sebanyak 49 orang dengan IR mencapai 145,92 per 100 ribu penduduk [4]. Berdasarkan uraian diatas maka peneliti ingin melakukan penelitian lebih lanjut untuk mengetahui hubungan pengetahuan dan praktik PSN dengan tempat perindukan vektor DBD di wilayah Puskesmas Banjarbaru Utara 2019.

\section{BAHAN DAN CARA PENELITIAN}

Desain penelitian yang digunakan adalah dengan menggunakan desain Cross Sectional (potong-lintang) adalah rancangan penelitian yang mencakup semua jenis penelitian dengan melakukan pengukuran variabel hanya satu kali, pada satu saat. Penelitian ini dilaksanakan pada bulan November 2018 sampai dengan bulan Mei tahun 2019. Populasi penelitian adalah keseluruhan objek penelitian atau objek yang di teliti tersebut [5]. Populasi dalam penelitian adalah populasi kepala keluarga di kedua kelurahan yang berada di wilayah Puskesmas Banjarbaru Utara adalah sebanyak 7.908 kepala keluarga. Teknik pengambilan sampel dengan menggunakan Cluster Random Sampling. Sampel dalam penelitian ini sebanyak 99 KK.

\section{HASIL DAN PEMBAHASAN}

Responden di Loktabat Utara terbanyak pada kelompok umur 31-40 Tahun (31,8\%) dan responden di Mentaos terbanyak juga pada kelompok umur 31-40 Tahun $(30,3 \%)$. Di Loktabat Utara tingkat pendidikan terakhir responden terbanyak pada pendidikan SD $(33,3 \%)$ dan di Mentaos tingkat pendidikan terakhir responden juga terbanyak pada pendidikan SD $(39,4 \%)$.

Distribusi pengetahuan responden tentang PSN di wilayah Puskesmas Banjarbaru Utara pada tahun 2019 seperti Tabel 1.

Tabel 1 Distribusi Pengetahuan PSN

\begin{tabular}{clcccc}
\hline No & $\begin{array}{c}\text { Pengetahuan } \\
\text { PSN }\end{array}$ & $\begin{array}{c}\text { Loktabat } \\
\text { Utara (org) }\end{array}$ & $\begin{array}{c}\text { Kelurahan } \\
\text { Mentaos } \\
\text { (org) }\end{array}$ & $\%$ \\
\hline 1 & Baik & 59 & 89,4 & 29 & 87,9 \\
2 & Tidak Baik & 7 & 10,6 & 4 & 12,1 \\
Total & & 66 & 100 & 33 & 100 \\
\hline
\end{tabular}


Responden di Loktabat Utara memiliki pengetahuan PSN yang baik sebesar 89,4\%, sedangkan responden di Mentaos memiliki pengetahuan PSN yang baik sebesar 87,9\%. Pengetahuan atau ranah kognitif merupakan domain yang sangat penting dalam membentuk tindakan seseorang (overt behavior) [6].

Distribusi praktik responden tentang PSN di wilayah Puskesmas Banjarbaru Utara pada tahun 2019 seperti Tabel 2.

Tabel 2 Distribusi Praktik PSN

\begin{tabular}{clcccc}
\hline No & Praktik PSN & $\begin{array}{c}\text { Kelurahan } \\
\text { Loktabat } \\
\text { Utara (org) }\end{array}$ & $\begin{array}{c}\text { Mentaos } \\
\text { (org) }\end{array}$ & $\%$ \\
\hline 1 & Baik & 0 & 0 & 0 & 0 \\
2 & Cukup & 48 & 72,7 & 18 & 54,5 \\
3 & Tidak Baik & 18 & 27,3 & 15 & 45,5 \\
Total & & 66 & 100 & 33 & 100 \\
\hline
\end{tabular}

Responden di Loktabat Utara memiliki praktik PSN yang cukup sebesar 72,7\%, sedangkan responden di Mentaos memiliki praktik PSN yang cukup sebesar 54,5\%. Praktik PSN terdiri dari berbagai aspek, yaitu: respons terpimpin (guided response), melakukan sesuatu sesuai dengan urutan yang benar dan sesuai dengan contoh, dalam hal ini masyarakat mampu melakukan upaya pencegahan timbulnya keberadaan jentik sesuai dengan pedoman yang ada, mekanisme (mechanism), melakukan sesuatu secara otomatis dan akan menjadi kebiasaan untuk melakukan pemberantasan sarang nyamuk [6]. Hubungan antara pengetahuan tentang PSN dan tempat perindukan vektor DBD di wilayah Puskesmas Banjarbaru Utara tahun 2019 seperti Tabel 3.

Tabel 3 Pengetahuan PSN dan Tempat Perindukan Vektor DBD

\begin{tabular}{lcccc}
\hline \multicolumn{1}{c}{$\begin{array}{c}\text { Pengetahuan } \\
\text { PSN }\end{array}$} & \multicolumn{4}{c}{ Tempat Perindukan Vektor DBD } \\
& Berisiko (org) & $\%$ & Tidak Berisiko (org) & $\%$ \\
\hline Tidak Baik & 9 & 28,1 & 3 & 4,5 \\
Baik & 23 & 71,9 & 64 & 95,5 \\
Total & 32 & 100 & 67 & 100 \\
$p=0,002$ & & & & \\
\hline
\end{tabular}

Hasil analisis statistik menggunakan chi square variabel pengetahuan dengan tempat perindukan vektor didapatkan nilai $p$ sebesar $0,002<\alpha(0,05)$, maka Ho ditolak. Artinya, ada hubungan yang bermakna antara pengetahuan masyarakat tentang PSN dengan tempat perindukan vektor DBD di wilayah Puskesmas Banjarbaru Utara Tahun 2019. Seseorang yang berpendidikan tinggi namun memiliki tingkat aktifitas yang tinggi (sibuk bekerja) sering kali lupa untuk melakukan tindakan pencegahan DBD. Selain itu, jenis atau spesifikasi pendidikan tinggi tapi tidak dalam bidang kesehatan [7].

Hubungan antara praktik PSN dan tempat perindukan vektor DBD di wilayah Puskesmas Banjarbaru Utara tahun 2019 seperti Tabel 4. 
Tabel 4 Praktik PSN dan Tempat Perindukan Vektor DBD

\begin{tabular}{lcccc}
\hline \multicolumn{1}{c}{ Praktik PSN } & \multicolumn{4}{c}{ Tempat Perindukan Vektor DBD } \\
& Berisiko (org) & $\%$ & Tidak Berisiko (org) & $\%$ \\
\hline Tidak Baik & 25 & 78,1 & 8 & 11,9 \\
Cukup & 7 & 21,9 & 59 & 88,1 \\
Total & 32 & 100 & 67 & 100 \\
$p=0,000$ & & & &
\end{tabular}

Hasil analisis statistik menggunakan chi square variabel tindakan dengan tempat perindukan vektor didapatkan nilai $p$ sebesar $0,000<\alpha(0,05)$, maka Ho ditolak. Artinya, ada hubungan yang bermakna antara praktik masyarakat dalam pelaksanaan PSN dengan tempat perindukan vektor DBD di wilayah Puskesmas Banjarbaru Utara Tahun 2019. Sebagian besar responden menjawab sering dan selalu melakukan pengurasan pada bak mandi atau wadah penampungan air sekurang-kurangnya seminggu sekali.

\section{KESIMPULAN DAN SARAN}

Pengetahuan masyarakat tentang PSN di wilayah Puskesmas Banjarbaru Utara Tahun 2019 di Loktabat Utara paling banyak kategori pengetahuan baik $(89,4 \%)$ dan di Mentaos paling banyak kategori pengetahuan baik $(87,9 \%)$. Praktik masyarakat tentang PSN di wilayah Puskesmas Banjarbaru Utara Tahun 2019 di Loktabat Utara paling banyak kategori praktik cukup $(72,7 \%)$ dan di Mentaos paling banyak kategori praktik cukup $(54,5 \%)$. Ada hubungan antara pengetahuan masyarakat tentang PSN dengan tempat perindukan vektor DBD di wilayah Puskesmas Banjarbaru Utara Tahun $2019 \quad(\mathrm{p}<\alpha)$ dan ada hubungan antara praktik masyarakat dalam pelaksanaan PSN dengan tempat perindukan vektor DBD di wilayah Puskesmas Banjarbaru Utara Tahun 2019 $(p<\alpha)$. Diharapkan masyarakat dapat berperan aktif dalam Pemberantasan Sarang Nyamuk dengan melakukan 3M khususnya dalam menguras tempat penampungan air serta menaburkan
Tetapi saat dilakukan observasi secara langsung, ada bak mandi yang masih terdapat jentiknya. Pada hasil penelitian [8] bahwa frekuensi pengurasan tempat penampungan air (TPA) mempunyai hubungan terhadap kejadian DBD. Hal ini disebabkan karena secara umum nyamuk meletakkan telurnya pada dinding TPA, oleh karena itu pada waktu pengurasan atau pembersihan TPA dianjurkan menggosok atau menyikat dindingdinding TPA untuk meminimalkan timbulnya keberadaan jentik.

bubuk abate ke dalam kontainer yang tidak dapat dikuras atau ditutup.

\section{KEPUSTAKAAN}

1. Achmadi UF. Dasar-Dasar Penyakit Berbasis Lingkungan. 2011;

2. RI K. Petunjuk Teknis Implementasi PSN 3M Plus dengan gerakan 1 rumah 1 jumantik. 2016.

3. Riyanto BC, Pascasarjana P, Maret US. Hubungan Tingkat Pendidikan, Pengetahuan Dan Sikap Ibu Rumah Tangga Dengan Kegiatan 3M Demam Berdarah Dengue Di Puskesmas Loa Ipuh Kabupaten Kutai Kartanegara. 2010;

4. Banjarbaru kota dinkes. Data Demam Berdarah tahun 2015-2018. 2018.

5. Notoatmodjo S. Metodologi Penelitian Kesehatan. Jakarta: PT. Rineka Cipta; 2012.

6. Notoatmodjo S. Promosi Kesehatan Dan Perilaku Kesehatan. Jakarta: PT. Rineka Cipta; 2014.

7. Montung D. Hubungan Antara Karakteristik Individu, Pengetahuan, Sikap Dengan Tindakan Masyarakat 
Dalam Pencegahan Demam Berdarah

Kolongan Minahasa Utara. 2012;

Dengue di Wilayah Kerja Puskesmas 
